\title{
Potential of Piperazinylalkylester Prodrugs of 6-Methoxy-2-Naphthylacetic Acid (6-MNA) for Percutaneous Drug Delivery
}

\author{
Vijay Pawar, ${ }^{1}$ Rushabh Thosani, ${ }^{1}$ Ashish Kanhed, ${ }^{1}$ Rajani Giridhar, ${ }^{1}$ and Mange Ram Yadav ${ }^{1,2}$
}

Received 15 April 2014; accepted 9 October 2014; published online 6 November 2014

\begin{abstract}
Piperazinylalkyl ester prodrugs (4a-5d) of 6-methoxy-2-naphthylacetic acid (6-MNA) (1) were synthesized and evaluated in vitro for the purpose of percutaneous drug delivery. These ionizable prodrugs exhibited varying aqueous solubilities and lipophilicities depending on the $\mathrm{pH}$ of the medium. The prodrugs (4a-5c) showed higher aqueous solubility and similar lipophilicity at pH 5.0 and lower aqueous solubility and higher lipophilicity at $\mathrm{pH} 7.4$ in comparison to 6-MNA. The chemical and enzymatic hydrolyses of the prodrugs was investigated in aqueous buffer solutions ( $\mathrm{pH} 5.0$ and 7.4) and in $80 \%$ human serum $\left(\mathrm{pH} \mathrm{7.4)}\right.$ at $37^{\circ} \mathrm{C}$. The prodrugs showed moderate chemical stability $\left(t_{1 / 2}=6-60 \mathrm{~h}\right)$ but got readily hydrolyzed enzymatically to 6-MNA with half-life ranging from 10-60 min. In the in vitro permeation study using rat skin, the flux of 6-MNA and the prodrugs was determined in aqueous buffers of pH 5.0 and 7.4. The prodrug (5b) showed 7.9- and 11.2-fold enhancement in skin permeation compared to 6-MNA (1) at pH 5.0 and 7.4, respectively. It was concluded that the parent NSAIDs having favorable pharmacokinetic and pharmacodynamic properties coupled with increased skin permeability of their prodrugs could give better options for the treatment of rheumatic diseases.
\end{abstract}

KEY WORDS: 6-MNA; NSAID; piperazinylalkylester; prodrug; skin permeation.

\section{INTRODUCTION}

Non-steroidal anti-inflammatory drugs (NSAIDs) are a class of drugs used for the treatment of rheumatic diseases and related painful conditions. Oral therapy using these agents is very effective but their clinical usage is often limited due to their adverse effects. Side effects of orally administered NSAIDs, such as ulceration potential and irritation of gastrointestinal mucosa (GI), have accelerated the development of alternative delivery systems for these drugs such as percutaneous drug delivery $(1,2)$. Application of NSAIDs through percutaneous route can also lead to increase in drug concentration in the local soft tissue and joints while reducing their distribution and systemic toxicity $(3,4)$. Unfortunately, the bioavailability of topically applied NSAIDs is only $1-2 \%$ in humans due to the barriers posed by the skin constituents $(3,5-7)$.

Various strategies have been developed over the years to improve percutaneous delivery of the NSAIDs which include salt formation, chemical modifications and devising novel formulations for the drugs. In most of the formulations, penetration enhancers have been used to increase skin permeability

Electronic supplementary material The online version of this article (doi:10.1208/s12249-014-0240-6) contains supplementary material, which is available to authorized users.

\footnotetext{
${ }^{1}$ Pharmacy Department, Faculty of Technology \& Engineering, The M.S. University of Baroda, Vadodara, 390001, India.

${ }^{2}$ To whom correspondence should be addressed. (e-mail: mryadav11@yahoo.co.in)
}

of the active ingredients. These penetration enhancers are chemicals that partition themselves into skin, interfere with the constituents of the skin layers and reduce the skin resistance for drug diffusion but may also lead to undesirable effects such as skin irritation, rashes and discomfort $(8,9)$. Salt formation has been considered as an alternative strategy for the delivery of such drugs as it enhances skin permeation of these drugs without modifying the molecular structure of the active parent drug (10). Masking of the polar carboxylic acid functional group of the NSAIDs via esterification has been investigated as a promising strategy of increasing the dermal permeation. Various morpholinyl and methylpiperazinyl prodrugs of naproxen and ketorolac have been developed and found to be stable with improved permeation through the skin. These prodrugs got hydrolyzed rapidly in vivo to release the active drugs $(1,5,11)$. Further, these prodrugs showed four- to nine-fold enhancement in skin permeation compared to the parent drugs.

Several current guidelines for management of osteoarthritis (OA) recommended topical NSAIDs, as safe and effective first line of treatment (12). In a recent study, nine commercially available topical NSAID formulations from the European Union have been studied for skin permeability, anti-inflammatory and analgesic responses. The study revealed that topical ketoprofen preparation showed superior results as compared to the other NSAID formulations (13). This study suggests that along with permeation enhancement, pharmacokinetic and pharmacodynamic properties of the NSAIDs are equally important parameters from the therapeutic point of view for the treatment of rheumatic diseases. A 
majority of the clinically used NSAIDs have short half lives, lack affinity towards the joints and possess large volume of distribution which adversely affect the treatment of chronic diseases such as arthritis. In order to obviate these drawbacks, we chose 6-methoxy-2-naphthylacetic acid (6-MNA), an active metabolite of nabumetone as the parent drug. It has certain advantages like having a long half-life (21-27 h), small volume of distribution $(7.5 \mathrm{~L})$, tendency to penetrate well into the synovial fluid, high binding to plasma proteins and absence of enterohepatic circulation. At the same time, it is a potent and selective inhibitor of cycloxygenase- 2 enzyme $(14,15)$. Combining these ideal features of 6-MNA with the successful approach of converting the parent drugs into ester prodrugs for topical delivery, and keeping in view some recent work in the field, we planned to synthesize and evaluate a series of novel substituted piperazinylalkyl esters as prodrugs of 6-MNA for potential percutaneous drug delivery (11,16-18).

\section{MATERIALS AND METHODS}

All reagents and solvents required for synthesis were purified by general laboratory techniques before use. Purity of the compounds and completion of the reactions were monitored by thin-layer chromatography (TLC) on silica gel plates $\left(60 \mathrm{~F}_{254}\right.$; Merck), visualizing with ultraviolet light or iodine vapors. The yields reported here are unoptimized. Compounds were purified by column chromatography wherever required using neutral aluminum oxide (active) as stationary phase and a suitable solvent as eluent.

Melting points were determined using a Veego-make silicon oil bath-type melting point apparatus and are uncorrected. The IR spectra were recorded using $\mathrm{KBr}$ disc method in per centimeter on a Bruker FT-IR, Model 8300. The PMR and ${ }^{13} \mathrm{C} \mathrm{NMR}$ (ppm) spectra were recorded in $\mathrm{CDCl}_{3} / \mathrm{DMSO}-$ $d_{6}$ on a Bruker $400 \mathrm{MHz}$ spectrometer (chemical shifts in $\delta$ ppm, coupling constant $J$ in $\mathrm{Hz}$ ). $\lambda_{\max }$ was determined on Shimadzu 1800 UV spectrophotometer. Mass of the compounds was determined by LCMS using electron impact as source of ionization. Human serum was obtained from Baroda Blood Bank and Hospital, Vadodara. In vitro skin permeation studies were conducted using Franz-type diffusion cell using skin obtained from the whole dorsal area of a male Wistar rat $(200 \pm 20 \mathrm{~g})$. Animal experiments were performed with the approval of the Institutional Animal Ethical Committee (MSU/PHARM/IAEC/2011/14) in accordance with Laboratory Animal Welfare guidelines.

\section{SYNTHESIS OF PRODRUGS}

\section{2-Bromoethyl 2-(6-Methoxy-2-Naphthyl)Acetate (2)}

In a round-bottomed flask $(250 \mathrm{ml}), 6-\mathrm{MNA}(\mathbf{1})(5.0 \mathrm{~g}$, $23.14 \mathrm{mM}$ ) was dissolved in dry dichloromethane (DCM) $(100 \mathrm{ml})$. The solution was cooled to $0-2^{\circ} \mathrm{C}$ followed by the addition of 1-ethyl-3-(3-dimethylaminopropyl)carbodiimide (EDC) $(5.30 \mathrm{~g}, 27.77 \mathrm{mM})$ into it with stirring and dimethylaminopyridine (DMAP) $(50 \mathrm{mg}$ ) was added into the reaction mixture as a catalyst followed by slow addition of 2-bromoethanol (4.90 ml, $69.44 \mathrm{mM})$. Stirring was continued till the reaction got completed. After completion of the reaction, the reaction mixture was washed with chilled water $(2 \times 100 \mathrm{ml})$ followed by washing with acetic acid $(10 \%, 2 \times$ $50 \mathrm{ml})$ and later with saturated solution of sodium bicarbonate $(2 \times 100 \mathrm{ml})$ and chilled water $(1 \times 100 \mathrm{ml})$. The organic layer was separated and dried over anhydrous sodium sulphate, filtered and the solvent removed on rota evaporator to afford yellow product. The crude product so obtained was recrystallized from methanol after decolorization with activated charcoal to afford a fluffy white product. The solid product was dried under vacuum at $40^{\circ} \mathrm{C} / 300 \mathrm{mmHg}(3.5 \mathrm{~g}$, $46.79 \%)$ m.p. $81-84^{\circ} \mathrm{C}$; TLC $\left(R_{\mathrm{f}}\right): 0.74$ (chloroform); UV $(\mathrm{MeOH}): 225 \mathrm{~nm}$; IR $\left(\mathrm{KBr}, \mathrm{cm}^{-1}\right)$ : 1727 and 1214; PMR $\left(\mathrm{CDCl}_{3}\right): \delta$ 7.71-7.67 (m, 3H, Ar-H), 7.39-7.37 (dd, $1 \mathrm{H}$, $\mathrm{Ar}-H, J=1.76), 7.15-7.11(\mathrm{~m}, 2 \mathrm{H}, \mathrm{Ar}-H), 4.42-4.39(\mathrm{t}, 2 \mathrm{H}$, $\left.-\mathrm{OCH}_{2}, J=6.08\right), 3.91\left(\mathrm{~s}, 3 \mathrm{H},-\mathrm{OCH}_{3}\right), 3.79\left(\mathrm{~s}, 2 \mathrm{H},-\mathrm{COCH}_{2}\right)$ and 3.51-3.48 (t, 2H, $\left.-\mathrm{CH}_{2} \mathrm{Br}, J=6.08\right)$; $\operatorname{Mass}(\mathrm{m} / \mathrm{z}): 323.32\left(\mathrm{M}^{+}\right)$.

\section{3-Bromoproyl 2-(6-Methoxy-2-Naphthyl)Acetate (3)}

The intermediate (3) was synthesized by the same procedure as mentioned for compound 2 using 6-MNA (1) (1.0 g, $4.62 \mathrm{mM})$, EDC (1.06 g, $5.55 \mathrm{mM})$, DMAP (50 mg) and 3-bromo-1-propanol $(0.62 \mathrm{ml}, 6.94 \mathrm{mM})$ to afford a yellow product. The crude product so obtained was recrystallized from methanol after decolorization with activated charcoal to afford a fluffy white product. The solid product (3) was dried under vacuum at $40^{\circ} \mathrm{C} / 300 \mathrm{mmHg}(0.8 \mathrm{~g}$, $51.25 \%)$ m.p. $44-46^{\circ} \mathrm{C}$; TLC $\left(R_{\mathrm{f}}\right): 0.81$ (chloroform); UV $(\mathrm{MeOH}): 225 \mathrm{~nm}$; IR (KBr, cm $\left.{ }^{-1}\right): 1735$ and 1267; PMR $\left(\mathrm{CDCl}_{3}\right): 7.71-7.68$ (dd, 2H, Ar- $\left.H, J=4.28\right), 7.64$ (s, $\left.1 \mathrm{H}, \mathrm{Ar}-H\right)$ 7.38-7.35 (m, 1H, Ar-H,), 7.15-7.11 (m, 2H, Ar-H), 4.25-4.22 $\left(\mathrm{t}, 2 \mathrm{H},-\mathrm{OCH}_{2}, J=6.56\right), 3.91\left(\mathrm{~s}, 3 \mathrm{H},-\mathrm{OCH}_{3}\right), 3.75(\mathrm{~s}, 2 \mathrm{H}$, $\left.-\mathrm{COCH}_{2}\right), 3.40-3.36\left(\mathrm{t}, 2 \mathrm{H},-\mathrm{CH}_{2} \mathrm{Br}, J=6.04\right)$ and $2.18-2.11$ (m, $\left.2 \mathrm{H},-\mathrm{CH}_{2}, J=6.56\right)$; Mass $(\mathrm{m} / \mathrm{z}): 337.23\left(\mathrm{M}^{+}\right)$.

\section{2-(4-Methylpiperazin-1-yl)Ethyl 2-(6-Methoxy-2-Naphthyl) Acetate (4a)}

The intermediate 2-bromoethyl 2-(6-methoxy-2naphthyl)acetate (2) (0.5 g, $1.54 \mathrm{mM})$ was dissolved in dry acetone $(20 \mathrm{ml})$ containing two drops of dimethyl formamide (DMF) in a pressure tube. $N$-Methylpiperazine $(0.46 \mathrm{~g}$, $4.64 \mathrm{mM})$ and potassium carbonate $(0.5 \mathrm{~g}, 3.62 \mathrm{mM})$ were added to the above reaction mixture. The tube was sealed and heated on an oil bath at $70-80^{\circ} \mathrm{C}$ with stirring. The reaction was monitored for completion, filtered to remove $\mathrm{K}_{2} \mathrm{CO}_{3}$ and then solvent recovered under vacuum to get a brown oily product which was purified by column chromatography using hexane:ethyl acetate $(1: 1)$ as the mobile phase and active neutral alumina as the stationary phase to yield a yellowish brown oil (4a) which failed to crystallize. The oily product so obtained was dried in a vacuum oven at $40^{\circ} \mathrm{C} / 300 \mathrm{mmHg}$ (0.44 g, 83\%); TLC $\left(R_{\mathrm{f}}\right): 0.43$ (chloroform:methanol; 9:1); $\mathrm{UV}\left(\mathrm{H}_{2} \mathrm{O}\right): 226 \mathrm{~nm}$; IR $\left(\mathrm{KBr}, \mathrm{cm}^{-1}\right): 1730,1264$ and 1148; PMR $\left(\mathrm{CDCl}_{3}\right): 7.63-7.03(\mathrm{~m}, 6 \mathrm{H}, \mathrm{Ar}-\mathrm{H}), 4.16-4.13(\mathrm{t}, 2 \mathrm{H}$, $\left.-\mathrm{OCH}_{2}, J=5.8\right), 3.83\left(\mathrm{~s}, 3 \mathrm{H},-\mathrm{OCH}_{3}\right), 3.68\left(\mathrm{~s}, 2 \mathrm{H},-\mathrm{OCH}_{2}\right), 2.54$ $2.51\left(\mathrm{t}, 2 \mathrm{H}, \mathrm{N}-\mathrm{CH}_{2}, J=5.8\right), 2.38-2.27(\mathrm{~m}, 8 \mathrm{H}$, piperazine- $H$ ) and $2.16\left(\mathrm{~s}, 3 \mathrm{H},-\mathrm{CH}_{3}\right) ;{ }^{13} \mathrm{C} \mathrm{NMR}\left(\mathrm{CDCl}_{3}\right)$ : 171.67 (1C, $\left.\mathrm{CO}\right), 157.62-$ $105.56(10 C, \mathrm{Ar}-\mathrm{C}), 62.31\left(1 \mathrm{C}, \mathrm{OCH}_{2}\right), 56.2\left(\mathrm{O}-\mathrm{CH}_{3}\right), 55.3-54.94$ (2C, piperazine), $52.93\left(1 \mathrm{C},-\mathrm{CH}_{2}-\mathrm{N}\right), 52.64-52.12(2 \mathrm{C}$, piperazine), $45.70\left(\mathrm{Ar}-\mathrm{CH}_{2}-\right)$ and $41.20\left(1 \mathrm{C},-\mathrm{N}-\mathrm{CH}_{3}\right)$; Mass 
$(\mathrm{m} / \mathrm{z})$ : $342.5\left(\mathrm{M}^{+}\right)$; anal. calcd for $\mathrm{C}_{20} \mathrm{H}_{26} \mathrm{O}_{3} \mathrm{~N}_{2}$ : C 70.15, H 7.65, N 8.17; found: $\mathrm{C} 70.32, \mathrm{H} \mathrm{7.43,} \mathrm{N} \mathrm{8.32;} \mathrm{chromatographic} \mathrm{purity}$ (HPLC): $>98.9 \%$.

\section{2-(4-Ethylpiperazin-1-yl)Ethyl 2-(6-Methoxy-2-Naphthyl) Acetate (4b)}

The derivative (4b) was synthesized by the same procedure as mentioned for (4a) taking 2-bromoethyl 2-(6-methoxy-2naphthyl)acetate (2) $(0.5 \mathrm{~g}, 1.54 \mathrm{mM})$ and $N$-ethylpiperazine $(0.21 \mathrm{~g}, 1.85 \mathrm{mM})$ to get an oily product which was purified by column chromatography using hexane:ethyl acetate (1:1) as the mobile phase and active neutral alumina as the stationary phase. The yellowish green oily product $(\mathbf{4 b})$ so obtained was dried in a vacuum oven at $40^{\circ} \mathrm{C} / 300 \mathrm{mmHg}(0.25 \mathrm{~g}, 45.45 \%)$; $\mathrm{TLC}\left(R_{\mathrm{f}}\right): 0.53$ (chloroform:methanol; 9:1); UV $\left(\mathrm{H}_{2} \mathrm{O}\right): 226 \mathrm{~nm}$; IR $\left(\mathrm{KBr}, \mathrm{cm}^{-1}\right)$ : 1731, 1264 and 1151; PMR $\left(\mathrm{CDCl}_{3}\right): 7.63-7.03(\mathrm{~m}, 6 \mathrm{H}, \mathrm{Ar}-H)$, 4.17-4.14 (t, 2H, $\left.-\mathrm{OCH}_{2}, J=5.76\right), 3.83\left(\mathrm{~s}, 3 \mathrm{H},-\mathrm{OCH}_{3}\right), 3.68$ $\left(\mathrm{s}, 2 \mathrm{H},-\mathrm{COCH}_{2}\right), 2.54-2.52\left(\mathrm{t}, 2 \mathrm{H},-\mathrm{CH}_{2} \mathrm{~N}, J=5.76\right), 2.38-2.37$ $(\mathrm{m}, 8 \mathrm{H}$, piperazine- $H), 2.31-2.26\left(\mathrm{q}, 2 \mathrm{H},-\mathrm{CH}_{2}, J=7.2\right)$ and $0.99-$ $0.95\left(\mathrm{t}, 3 \mathrm{H},-\mathrm{CH}_{3}, J=7.16\right)$; Mass $(\mathrm{m} / \mathrm{z})$ : $356.38\left(\mathrm{M}^{+}\right)$; anal. calcd for $\mathrm{C}_{21} \mathrm{H}_{28} \mathrm{O}_{3} \mathrm{~N}_{2}$ : C 70.76, H 7.91, N 7.85; found: C 70.96, H 7.74, N 7.68; chromatographic purity (HPLC): $>97.8 \%$.

\section{2-(4-Acetylpiperazin-1-yl)Ethyl 2-(6-Methoxy-2-Naphthyl) Acetate (4c)}

The derivative $(\mathbf{4 c})$ was synthesized by the procedure as mentioned for (4a) using 2-bromoethyl 2-(6-methoxy-2naphthyl)acetate (2) $(0.5 \mathrm{~g}, 1.54 \mathrm{~mm})$ and $N$-acetylpiperazine $(0.23 \mathrm{~g}, 1.84 \mathrm{mM})$ to afford an oily product which was purified by column chromatography using hexane: ethyl acetate (1:1) as the mobile phase and active neutral alumina as the stationary phase. The red brown oily product (4c) so obtained was dried in vacuum oven at $40^{\circ} \mathrm{C} / 300 \mathrm{mmHg}(0.17 \mathrm{~g}, 34.88 \%)$; TLC $\left(R_{\mathrm{f}}\right)$ : 0.56 (chloroform:methanol; 9:1); UV $\left(\mathrm{H}_{2} \mathrm{O}\right)$ : $225 \mathrm{~nm}$; IR $\left(\mathrm{KBr}, \mathrm{cm}^{-1}\right)$ : 1730, 1626, 1263 and 1150; PMR $\left(\mathrm{CDCl}_{3}\right)$ : 7.63-7.03 (m, 6H, Ar-H), 4.16-4.13 (t, 2H, $-\mathrm{OCH}_{2}$, $J=5.44), 3.82\left(\mathrm{~s}, 3 \mathrm{H},-\mathrm{OCH}_{3}\right), 3.67$ (s, $\left.2 \mathrm{H},-\mathrm{COCH}_{2}\right), 3.13-$ $3.11\left(\mathrm{t}, 2 \mathrm{H}, \mathrm{N}-\mathrm{CH}_{2}, J=5.0\right), 2.52-2.50(\mathrm{~m}, 4 \mathrm{H}$, piperazine- $H)$, 2.29-2.19 (m, 4H, piperazine- $H$ ) and $1.90\left(\mathrm{~s}, 3 \mathrm{H},-\mathrm{COCH}_{3}\right)$; Mass $(\mathrm{m} / \mathrm{z})$ : $370.45\left(\mathrm{M}^{+}\right)$; anal. calcd for $\mathrm{C}_{21} \mathrm{H}_{26} \mathrm{O}_{4} \mathrm{~N}_{2}$ : C 68.09, $\mathrm{H}$ 7.07, N 7.55; found: C 68.28, H 7.24, N 7.75; chromatographic purity (HPLC): $>97.4 \%$.

\section{2-(4-Phenylpiperazin-1-yl)Ethyl 2-(6-Methoxy-2-Naphthyl) Acetate (4d)}

The derivative (4d) was synthesized by the same procedure as mentioned for (4a) using 2-bromoethyl 2-(6-methoxy-2naphthyl)acetate (2) $(0.5 \mathrm{~g}, 1.54 \mathrm{mM})$ and $N$-phenylpiperazine $(0.30 \mathrm{~g}, 1.85 \mathrm{mM})$ to afford a crude solid product which was successively recrystallized from methanol to yield white solid (4d). The product was dried in a vacuum oven at $60^{\circ} \mathrm{C} / 300 \mathrm{mmHg}$ (0.3 g, 47.91\%) m.p. $91-93^{\circ} \mathrm{C}$; TLC $\left(R_{\mathrm{f}}\right): 0.69$ (chloroform:methanol; 9:1); UV ( $\left.\mathrm{H}_{2} \mathrm{O}\right): 226 \mathrm{~nm}$; IR $\left(\mathrm{KBr}, \mathrm{cm}^{-1}\right): 1720,1234$ and 1147; PMR $\left(\mathrm{CDCl}_{3}\right)$ : 7.70-7.22 (m, 6H, Ar- H), 7.15-6.80 (m, 5H, phenyl- $H$ ), 4.29-4.27 (t, 2H, $\left.-\mathrm{OCH}_{2}, J=5.56\right), 3.90(\mathrm{~s}, 3 \mathrm{H}$, $\left.-\mathrm{OCH}_{3}\right), 3.77\left(\mathrm{~s}, 2 \mathrm{H},-\mathrm{COCH}_{2}\right), 3.02-2.95(\mathrm{t}, 4 \mathrm{H}$, piperazine- $H$, $J=5.10), 2.67-2.64\left(\mathrm{t}, 2 \mathrm{H}, \mathrm{N}-\mathrm{CH}_{2}, J=5.56\right)$ and $2.52-2.49(\mathrm{t}, 4 \mathrm{H}$, piperazine- $H, J=5.10)$; Mass $(\mathrm{m} / z)$ : $404.56\left(\mathrm{M}^{+}\right)$; anal. calcd for
$\mathrm{C}_{25} \mathrm{H}_{28} \mathrm{O}_{3} \mathrm{~N}_{2}$ : C 74.23, H 6.97, N 6.92; found: C 74.41, H 7.12, N 7.09; Chromatographic Purity (HPLC): $>98.7 \%$.

\section{3-(4-Methylpiperazin-1-yl)Propyl 2-(6-Methoxy-2-Naphthyl) Acetate (5a)}

Derivative (5a) was synthesized by the same procedure as mentioned for (4a) using the intermediate 3-bromoproyl 2-(6methoxy-2-naphthyl)acetate (3) $(0.3 \mathrm{~g}, 0.890 \mathrm{mM})$ and $N$ methylpiperazine $(0.106 \mathrm{~g}, 1.068 \mathrm{mM})$ to afford a brown oily product. The oily product was purified by column chromatography using hexane:ethyl acetate (1:1) as the mobile phase and neutral alumina as the stationary phase to yield a brown oily product (5a) which failed to crystallize. The product so obtained was dried in a vacuum oven at $40^{\circ} \mathrm{C} / 300 \mathrm{mmHg}$ $(0.15 \mathrm{~g}, 48.31 \%)$; TLC $\left(R_{\mathrm{f}}\right)$ : 0.60 (chloroform:methanol; 10:0.5); UV $\left(\mathrm{H}_{2} \mathrm{O}\right): 226 \mathrm{~nm}$; IR $\left(\mathrm{KBr}, \mathrm{cm}^{-1}\right): 1732,1398$ and 1163; PMR $\left(\mathrm{CDCl}_{3}\right)$ : 7.63-7.03 (m, 6H, Ar-H), 4.07$4.04\left(\mathrm{t}, 2 \mathrm{H},-\mathrm{OCH}_{2}, J=6.48\right), 3.81\left(\mathrm{~s}, 3 \mathrm{H},-\mathrm{OCH}_{3}\right), 3.64(\mathrm{~s}$, $\left.2 \mathrm{H},-\mathrm{COCH}_{2}\right), 2.34-2.28(\mathrm{~m}, 8 \mathrm{H}$, piperazine- $H), 2.27-2.23$ $\left(\mathrm{t}, 2 \mathrm{H},-\mathrm{NCH}_{2}, \mathrm{~J}=7.24\right), 2.16\left(\mathrm{~s}, 3 \mathrm{H}, \mathrm{N}-\mathrm{CH}_{3}\right)$ and $1.75-1.69$ $\left(\mathrm{m}, 2 \mathrm{H},-\mathrm{C}-\mathrm{CH}_{2}, J=7.04\right) ;{ }^{13} \mathrm{C} \mathrm{NMR}\left(\mathrm{CDCl}_{3}\right): 172.76$, 168.92-105.56, 62.94, 55.32-21.31; mass $(\mathrm{m} / \mathrm{z})$ : $356.42\left(\mathrm{M}^{+}\right)$; anal. calcd for $\mathrm{C}_{21} \mathrm{H}_{28} \mathrm{O}_{3} \mathrm{~N}_{2}$ : C 70.76, $\mathrm{H}$ 7.91, N 7.85; found: $\mathrm{C}$ 70.84, H 8.13, N 7.98; chromatographic purity (HPLC): $>98.5 \%$.

\section{3-(4-Ethylpiperazin-1-yl)Propyl 2-(6-Methoxy-2-Napthyl) Acetate (5b)}

Derivative (5b) was synthesized by the same procedure as described for (4a) using the intermediate 3-bromoproyl 2(6-methoxy-2naphthyl)acetate (3) and $N$-ethylpiperazine $(0.12 \mathrm{~g}, 1.0 \mathrm{mM})$ to afford brown oily product. The product was purified by column chromatography using hexane: ethyl acetate (1:1) as the mobile phase and neutral alumina as the stationary phase to yield brown oily product which failed to crystallize. The product (5b) so obtained was dried in a vacuum oven at $40^{\circ} \mathrm{C} / 300 \mathrm{mmHg}(0.20 \mathrm{~g}$, $62.50 \%)$; TLC $\left(R_{\mathrm{f}}\right): 0.40$ (chloroform:methanol; 10:0.5); $\mathrm{UV}\left(\mathrm{H}_{2} \mathrm{O}\right): 226 \mathrm{~nm}$; IR $\left(\mathrm{KBr}, \mathrm{cm}^{-1}\right): 1732,1265$ and 1156; PMR $\left(\mathrm{CDCl}_{3}\right)$ : 7.55-6.95 (m, 6H, Ar-H), 3.99-3.96 $\left(\mathrm{t}, 2 \mathrm{H},-\mathrm{OCH}_{2}, \mathrm{~J}=6.4\right), 3.75\left(\mathrm{~s}, 3 \mathrm{H},-\mathrm{OCH}_{3}\right), 3.54\left(\mathrm{~s}, 2 \mathrm{H},-\mathrm{CH}_{2}\right)$, $2.50-2.47\left(\mathrm{t}, 2 \mathrm{H}, \mathrm{N}-\mathrm{CH}_{2}\right), 2.42-2.26(\mathrm{~m}, 8 \mathrm{H}$, piperazine- $H), 2.21-$ $2.19\left(\mathrm{~m}, 2 \mathrm{H},-\mathrm{N}-\mathrm{CH}_{2}\right), 1.58-1.55\left(\mathrm{~m}, 2 \mathrm{H},-\mathrm{CH}_{2^{-}}, \mathrm{J}=4.88\right)$ and 0.97-0.94 (m, 3H, $\left.-\mathrm{CH}_{3}\right)$; Mass $(\mathrm{m} / \mathrm{z})$ : $370.39\left(\mathrm{M}^{+}\right)$; anal. calcd for $\mathrm{C}_{22} \mathrm{H}_{30} \mathrm{O}_{3} \mathrm{~N}_{2}$ : C 71.32, H 8.16, N 7.55; found: C 71.56, H 8.45, N 7.72; chromatographic purity (HPLC): $>98.3 \%$.

\section{3-(4-Acetylpiperazin-1-yl)Propyl 2-(6-Methoxy-2-Napthyl) Acetate (5c)}

Derivative (5c) was synthesized by the same procedure as described for (4a) using the intermediate 3-bromoproyl 2-(6-methoxy-2-naphthyl)acetate (3) and $N$-acetylpiperazine $(0.22 \mathrm{~g}, 1.78 \mathrm{mM})$ to afford a brown oily product which was purified by column chromatography using hexane: ethyl acetate (1:1) as the mobile phase and neutral alumina as stationary phase to yield a brown oily product $(\mathbf{5 c})$ which failed to crystallize. The product thus obtained was dried in a vacuum oven at $40^{\circ} \mathrm{C} / 300 \mathrm{mmHg}(0.51 \mathrm{~g}, 89.47 \%)$; TLC $\left(R_{\mathrm{f}}\right): 0.51$ (chloroform:methanol; 19:1); UV $\left(\mathrm{H}_{2} \mathrm{O}\right): 226 \mathrm{~nm}$; 
IR $\left(\mathrm{KBr}, \mathrm{cm}^{-1}\right): 1728,1632,1263$ and 1150; PMR $\left(\mathrm{CDCl}_{3}\right)$ : 7.70-7.11 (m, 6H, Ar-H), 4.17-4.13 (t, 2H, -OCH,$J=6.4)$, $3.91\left(\mathrm{~s}, 3 \mathrm{H},-\mathrm{OCH}_{3}\right), 3.73\left(\mathrm{~s}, 2 \mathrm{H},-\mathrm{COCH}_{2}\right), 3.57-3.54$ $\left(\mathrm{t}, 2 \mathrm{H}, \mathrm{N}-\mathrm{CH}_{2}, J=5.12\right), 3.38-3.35(\mathrm{t}, 2 \mathrm{H}$, piperazine $-H)$, 2.33-2.27 (m, 6H, piperazine- $H) 2.05\left(\mathrm{~s}, 3 \mathrm{H},-\mathrm{COCH}_{3}\right)$, 1.80-1.77 and $\left(\mathrm{m}, 2 \mathrm{H},-\mathrm{CH}_{2}, J=5.12\right) ;{ }^{13} \mathrm{C} \mathrm{NMR}\left(\mathrm{CDCl}_{3}\right)$ : $\delta 171.76$ (1C, -CO), 168.92 (1C, -CO), 157.65-105.56 (10C, ArC), $62.94\left(1 \mathrm{C},-\mathrm{OCH}_{2}\right), 55.32\left(1 \mathrm{C},-\mathrm{OCH}_{3}\right), 54.57\left(1 \mathrm{C}, \mathrm{N}-\mathrm{CH}_{2}\right)$, 53.05-52.60 (2C, piperazine- $C$ ), $46.04\left(1 \mathrm{C},-\mathrm{CH}_{2} \mathrm{CO}\right), 41.50-41.18$ (2C, piperazine- $C), 25.80\left(1 \mathrm{C},-\mathrm{CH}_{2}\right)$ and $21.31\left(1 \mathrm{C},-\mathrm{CH}_{3}\right)$; mass $(\mathrm{m} / \mathrm{z})$ : $384.38\left(\mathrm{M}^{+}\right)$; anal. calcd for $\mathrm{C}_{22} \mathrm{H}_{28} \mathrm{O}_{4} \mathrm{~N}_{2}$ : C 68.73, $\mathrm{H} 7.34, \mathrm{~N}$ 7.28; found: C 68.92, H 7.16, N 7.09; chromatographic purity (HPLC): $>97.8 \%$.

\section{3-(4-Phenylpiperazin-1-yl)Propyl 2-(6-Methoxy-2-Naphthyl) Acetate (5d)}

Derivative (5d) was synthesized by the same procedure as described for (4a) using the intermediate 3-bromoproyl 2(6-methoxy-2-naphthyl)acetate (3) and $N$-phenylpiperazine $(0.28 \mathrm{~g}, 1.78 \mathrm{mM})$ to afford solid crude product which was repeatedly recrystallized from methanol to yield a light brown solid (5d). The product was dried in vacuum oven at $60^{\circ} \mathrm{C} / 300 \mathrm{mmHg}(0.3 \mathrm{~g}, 48.32 \%)$ m.p. $78-80^{\circ} \mathrm{C}$; TLC $\left(R_{\mathrm{f}}\right)$ : 0.73 (chloroform:methanol; 1:0.05); UV $\left(\mathrm{H}_{2} \mathrm{O}\right): 227 \mathrm{~nm}$; IR $\left(\mathrm{KBr}, \mathrm{cm}^{-1}\right): 1736,1267$ and 1155; $\mathrm{PMR}\left(\mathrm{CDCl}_{3}\right): \delta 7.63-$ $7.15(\mathrm{~m}, 6 \mathrm{H}, \mathrm{Ar}-H), 7.07-6.75(\mathrm{~m}, 5 \mathrm{H}$, phenyl-H), 4.11-4.07 $\left(\mathrm{t}, 2 \mathrm{H},-\mathrm{OCH}_{2}, J=6.44\right), 3.81\left(\mathrm{~s}, 3 \mathrm{H},-\mathrm{OCH}_{3}\right), 3.66(\mathrm{~s}, 2 \mathrm{H},-$ $\left.\mathrm{CH}_{2} \mathrm{CO}\right), 3.06-3.04(\mathrm{t}, 4 \mathrm{H}$, piperazine- $H, J=4.88), 2.43-2.40$ $(\mathrm{t}, 4 \mathrm{H}$, piperazine- $H, J=5.04), 2.32-2.28\left(\mathrm{t}, 2 \mathrm{H}, \mathrm{N}-\mathrm{CH}_{2}, J=7.2\right)$ and 1.77-1.73 (m, 2H, $\left.-\mathrm{CH}_{2}, J=7.64\right)$; mass $(\mathrm{m} / \mathrm{z}): 418.14\left(\mathrm{M}^{+}\right)$; anal. calcd for $\mathrm{C}_{26} \mathrm{H}_{30} \mathrm{O}_{3} \mathrm{~N}_{2}$ : C 74.61, H 7.22, N 6.69; found: $\mathrm{C} 74.39, \mathrm{H} 7.41, \mathrm{~N} 6.88$; chromatographic purity (HPLC): $>99.6 \%$.

\section{HPLC Analysis}

High-performance liquid chromatography (HPLC) was used for analysis. The analytical system consisted of an LC system (LC-20AD, Shimadzu USA) and UV-visible detector (SPD 20A, Shimadzu). The chromatographic separation was carried out under isocratic reverse phase conditions on purospher RP-18C column $(250 \times 4.6 \mathrm{~mm}, 5 \mu$, Merck Germany) with column temperature $25-28^{\circ} \mathrm{C}$. The injection volume was $20 \mu \mathrm{L}$ and the detection wavelength was $227 \mathrm{~nm}$. The mobile phase consisted of a mixture of $15 \mathrm{mM}$ phosphate buffer and acetonitrile of $\mathrm{pH} 5.0-5.5$ and the flow rate was $0.9 \mathrm{ml} / \mathrm{min}$.

\section{Aqueous Solubility}

The aqueous solubility of 6-MNA and its prodrugs were determined in phosphate buffer $(0.16 \mathrm{M})$ at $\mathrm{pH} 5.0$ and 7.4 at room temperature. Excess amounts of the prodrugs were added to phosphate buffer $(0.5-1 \mathrm{ml})$, the mixture stirred and centrifuged at $8000 \mathrm{rpm}$ and filtered (Millipore $0.45 \mu \mathrm{m}$ ). The concentrations of each prodrug in their saturated solutions were analyzed by HPLC. The $\mathrm{pH}$ of the solutions was held constant throughout the experiment $(1,7)$.

\section{Apparent Partition Coefficient $\left(\log \boldsymbol{P}_{\text {app }}\right)$}

The apparent partition coefficients $\left(\log P_{\text {app }}\right)$ of 6-MNA and its prodrugs were determined at room temperature between 1-octanol and phosphate buffer $(0.16 \mathrm{M})$ at pH 5.0 and 7.4 using shake flask method. 1-Octanol was saturated with phosphate buffer $(0.16 \mathrm{M})$ for $24 \mathrm{~h}$ by stirring vigorously before use. A known concentration of the compound in phosphate buffer was shaken with a suitable fixed volume of 1octanol. After shaking, both the phases were separated by centrifugation at $8000 \mathrm{rpm}$ for 5-6 min. The concentrations of the compounds in the buffer phase and in the 1-octanol phase were determined by HPLC $(1,7)$.

\section{Hydrolysis in Aqueous Solution}

Stability study or the rates of chemical hydrolysis of the prodrugs were carried out in aqueous phosphate buffer solutions $(0.16 \mathrm{M}$, ionic strength was adjusted to 0.5 with $\mathrm{NaCl})$ of pH 5.0 and 7.4 at $37 \pm 1^{\circ} \mathrm{C}$. An appropriate amount of the prodrug was dissolved in phosphate buffer $(5 \mathrm{ml})$ and the solutions were placed in a thermostatically controlled water bath at temperature $37 \pm 1^{\circ} \mathrm{C}$. Depending upon stability of each prodrug, samples were withdrawn at appropriate time intervals and analyzed for the intact amount of the prodrug and the liberated 6-MNA using HPLC. The experiments were run in triplicates for each compound. Half-lives $\left(t_{1 / 2}\right)$ for the hydrolysis of the different prodrugs were calculated from the slope of the linear portion of the plotted logarithm of the remaining concentrations of the prodrugs versus time $(1,7)$. The first-order equation $\left(t_{1 / 2}=0.693 / \mathrm{k}\right)$ was used to calculate the half-lives as the prodrugs were found to degrade by pseudo-first-order degradation kinetics.

\section{Hydrolysis in Human Serum}

The rates of enzymatic hydrolysis for prodrugs were studied in human serum at $37 \pm 1^{\circ} \mathrm{C}$. The human serum was diluted to $80 \%$ with $0.16 \mathrm{M}$ phosphate buffer, $\mathrm{pH} 7.4$. The study was performed by dissolving an appropriate amount of prodrug in phosphate buffer and human serum mixture. The solutions were maintained at $37 \pm 1^{\circ} \mathrm{C}$ in water bath and $0.5 \mathrm{ml}$ of serum/buffer mixture were withdrawn at appropriate time intervals and added to $1.0 \mathrm{ml}$ of ethanol to precipitate the proteins from the serum. Then, the mixture was centrifuged for $10 \mathrm{~min}$ at $10,000 \mathrm{rpm}$, the supernatant was analyzed for the released 6-MNA and the remaining prodrug by HPLC. The pseudo-first-order times, at which $50 \%$ total parent compound had been formed were determined from the linear slope of the logarithm of formed parent compound over various time intervals $(1,5)$.

\section{In Vitro Skin Permeation Studies}

In vitro skin permeation studies of 6-MNA and prodrugs were performed by using glass Franz diffusion cells and skin from the whole dorsal area of a male Wistar rat. The skin specimens were dried and frozen prior to use and rehydrated before being mounted in the diffusion cell. The receptor medium (0.05 $\mathrm{M}$ phosphate buffer saline solution of $\mathrm{pH}$ 7.4) was stirred and kept at $37 \pm 1^{\circ} \mathrm{C}$ throughout the study. The 
prodrugs were applied as solutions in phosphate buffer $(0.05 \mathrm{M})$ at both $\mathrm{pH} 5.0$ and 7.4. Infinite dose technique was used to determine the permeation profile of 6-MNA and the prodrugs in which excess amount of the test compound was used and the increase in the amount of the prodrug and/or parent along the experiments time frame was measured (19).

The receiver medium $(0.05 \mathrm{M}$ phosphate buffer saline solution of $\mathrm{pH} 7.4$ ) was stirred and kept at $37 \pm 1^{\circ} \mathrm{C}$ throughout the study. The prodrugs were applied as solutions in phosphate buffer of $\mathrm{pH} 5.0$ and 7.4. At specified time intervals, aliquots $(0.25 \mathrm{ml})$ were withdrawn from the receptor compartment and replaced with fresh buffer. The drug concentrations were analyzed by HPLC. The steady-state flux for 6-MNA (1) and its prodrugs were determined by plotting the cumulative amount of the parent drug and the intact prodrug as measured in the receiver phase against time, and dividing the slope of the steady-state position by the surface area of the diffusion cell $\left(4.906 \mathrm{~cm}^{2}\right)$. The permeability coefficients $\left(K_{\mathrm{p}}\right)$ for the steady-state delivery were obtained by dividing the steadystate flux $\left(J_{\mathrm{ss}}\right)$ by the solubilities of the prodrugs in the corresponding vehicle $(1,7)$.

\section{Statistical Analysis}

For testing the statistical significance of the data, Graph Pad Prism software was used. Data is presented as mean \pm standard deviation $(n=3-6)$. Groups were compared using analysis of variance (ANOVA) one-way test. Differences were considered statistically significant when $p<0.05$.

\section{RESULTS AND DISCUSSION}

\section{Synthesis of Piperazinylalkyl Ester Prodrugs of 6-MNA}

6-MNA (1) required for the synthesis of the prodrugs has been prepared by the reported procedure $(20,21)$. Scheme 1 was employed to synthesize piperazinylalkyl ester prodrugs $(\mathbf{4 a - 5 d )}$ of 6 -MNA (1). The ester intermediates $(\mathbf{2}, \mathbf{3})$ were prepared by coupling the corresponding bromoalkanol with 6MNA (1) using EDC as the coupling agent. The structures of the intermediates were confirmed by IR and NMR spectroscopy. Intermediate (2) showed strong absorption peak at $1727 \mathrm{~cm}^{-1}$ in the IR spectrum due to carbonyl stretching of the ester group. Its PMR spectrum showed multiplet at $\delta 7.71-$ 7.11 of six naphthalene protons $(\mathrm{Ar}-H)$, a triplet at $\delta 4.42-4.39$ due to methylene protons $\left(-\mathrm{CH}_{2}\right)$ with coupling constant equal to $6.08 \mathrm{~Hz}$. Methoxy protons $\left(-\mathrm{OCH}_{3}\right)$ appeared at $\delta$ 3.91 as singlet and methylene protons attached to aromatic ring $\left(-\mathrm{CH}_{2}\right)$ appeared at $\delta 3.79$. A triplet due to methylene protons $\left(-\mathrm{CH}_{2}\right)$ was observed at $\delta 3.51-3.48$ with coupling constant equal to $6.08 \mathrm{~Hz}$.

Similarly, another intermediate (3) showed strong absorption peak at $1,735 \mathrm{~cm}^{-1}$ due to carbonyl stretching of the ester group. The PMR spectrum of intermediate (3) showed multiplet at $\delta$ 7.71-7.11 for the six naphthalene protons $(\mathrm{Ar}-H)$ and methylene protons $\left(-\mathrm{CH}_{2}\right)$ appeared at $\delta 4.25-4.22$ as a triplet with coupling constant equal to $6.4 \mathrm{~Hz}$. Methoxy protons $\left(-\mathrm{OCH}_{3}\right)$ showed a singlet at $\delta 3.91$ and a singlet of methylene protons attached to aromatic ring $\left(\mathrm{Ar}-\mathrm{CH}_{2}\right)$ appeared at $\delta$ 3.75. Other methylene protons $\left(-\mathrm{CH}_{2}\right)$ appeared at $\delta 3.40-3.36$ as a triplet with coupling constant equal to $6.04 \mathrm{~Hz}$. Multiplet at $\delta 2.18-2.11$ appeared due to methylene protons $\left(-\mathrm{CH}_{2}\right)$ with coupling constant equal to $J=6.56 \mathrm{~Hz}$. These bromoalkyl ester intermediates $(\mathbf{2}, \mathbf{3})$ were further treated with appropriate piperazine derivatives (a-d) to get piperazinylalkyl ester prodrugs (4a-5d) of 6-MNA (1).

The IR spectrum of the ester (4a) showed absorption peak at $1730 \mathrm{~cm}^{-1}$ due to the carbonyl stretching of the ester group. The peaks at 1264 and $1148 \mathrm{~cm}^{-1}$ are due to $\mathrm{C}-\mathrm{O}$ and $\mathrm{C}-\mathrm{N}$ stretching vibrations, respectively. Its PMR spectrum showed multiplet at $\delta 7.63-7.03$ for six naphthalene protons $(\mathrm{Ar}-\mathrm{H})$ and a triplet at $\delta 4.16-4.13$ due to methylene $\left(-\mathrm{CH}_{2}\right)$ protons with coupling constant equal to $5.8 \mathrm{~Hz}$. A singlet due to methoxy protons $\left(-\mathrm{CH}_{3}\right)$ appeared at $\delta 3.83$ and of methylene $\left(\mathrm{Ar}-\mathrm{CH}_{2}\right)$ at $\delta 3.68$. The other methylene protons $\left(\mathrm{N}-\mathrm{CH}_{2}\right)$ showed triplet at $\delta$ 2.54-2.51 with coupling constant equal to $5.8 \mathrm{~Hz}$. The piperazine protons appeared as multiplet at $\delta 2.38-2.27$ and $N$-methyl protons $\left(-\mathrm{CH}_{3}\right)$ at $\delta$ 2.16 as a singlet.

Its ${ }^{13} \mathrm{C}$ NMR spectrum shows peak at 171.67 for carbonyl carbon. Aromatic carbons of naphthalene ring appear in the range of $\delta 157.62-105.56$. Methoxy carbon appears at $\delta 56.2$ and $-\mathrm{OCH}_{2}$ at $\delta 62.31$. Four piperazine carbons were observed at $\delta$ 52.12-55.3. Other aliphatic carbons appeared at $\delta 52.93$ $\left(\mathrm{N}-\mathrm{CH}_{2}\right), \delta 45.70\left(\mathrm{Ar}-\mathrm{CH}_{2}-\right)$ and $\delta 41.20\left(\mathrm{C}, \mathrm{N}-\mathrm{CH}_{3}\right)$. Mass spectrum shows molecular ion peak at $342.5\left(\mathrm{M}^{+}\right)$and also $\mathrm{M}+2$ peak at 344.0 which is the base peak. The compound showed high chromatographic purity (>98.2\%) by HPLC.

Representative compound (5a) from the second series was confirmed in a similar way and its IR spectrum showed a strong absorption peak at $1,732 \mathrm{~cm}^{-1}$ due to carbonyl

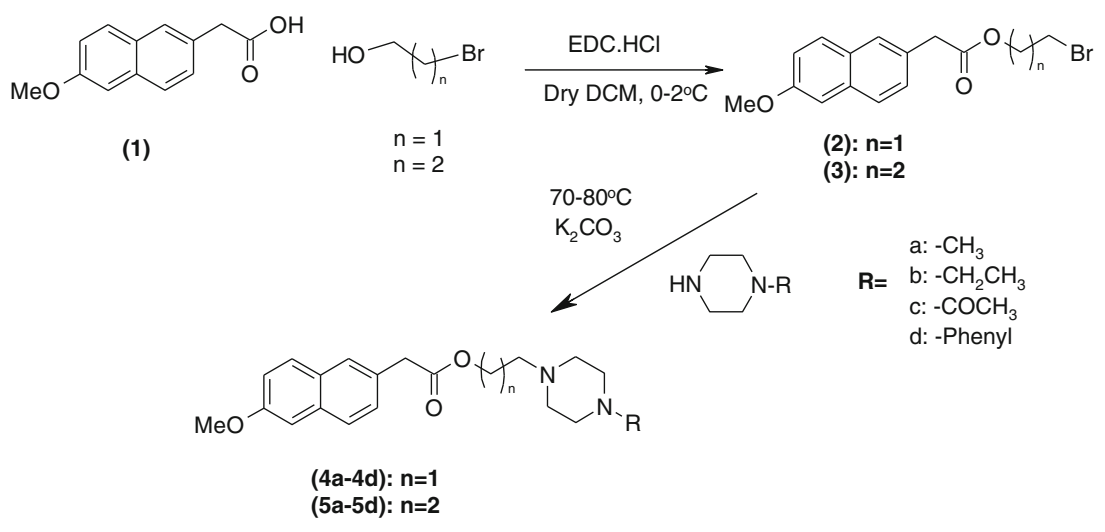

Scheme 1. Synthesis of piperazinylalkyl ester prodrugs 
Table I. Predicted Protonated Forms Obtained for Derivatives (4a-5d) at $\mathrm{pH}$ 5.0, 7.4 and Predicted $\mathrm{p} K_{\mathrm{a}}$ of 6-MNA (1) and its Derivatives at Physiological pH 7.4 Using $\mathrm{H}_{2} \mathrm{O}$ as Solvent

\begin{tabular}{|c|c|c|c|c|c|c|c|c|}
\hline \multirow[b]{3}{*}{ Entry ID } & \multirow[b]{3}{*}{$n$} & \multirow[b]{3}{*}{$R$} & \multicolumn{4}{|c|}{$\begin{array}{l}\text { Protonation } \\
\text { of nitrogen }\end{array}$} & & \\
\hline & & & \multicolumn{2}{|c|}{ pH 5.0} & \multicolumn{2}{|c|}{$\mathrm{pH} 7.4$} & \multicolumn{2}{|c|}{ Predicted $\mathrm{p} K_{\mathrm{a}}$} \\
\hline & & & $\mathrm{N}^{1}$ & $\mathrm{~N}^{4}$ & $\mathrm{~N}^{1}$ & $\mathrm{~N}^{4}$ & $\mathrm{p} K_{\mathrm{a}} 1$ & $\mathrm{p} K_{\mathrm{a}} 2$ \\
\hline 1 & - & - & - & - & - & - & 4.316 & - \\
\hline $4 \mathbf{a}$ & 1 & $-\mathrm{CH}_{3}$ & + & + & -- & -- & 3.572 & 7.719 \\
\hline 4a-1 & 1 & $-\mathrm{CH}_{3}$ & - & - & + & -- & - & - \\
\hline $4 a-2$ & 1 & $-\mathrm{CH}_{3}$ & - & - & -- & + & - & - \\
\hline $4 a-3$ & 1 & $-\mathrm{CH}_{3}$ & - & - & + & + & - & - \\
\hline $4 b$ & 1 & $-\mathrm{CH}_{2} \mathrm{CH}_{3}$ & + & + & -- & -- & 3.657 & 7.863 \\
\hline $4 b-1$ & 1 & $-\mathrm{CH}_{2} \mathrm{CH}_{3}$ & - & - & + & -- & - & - \\
\hline $4 b-2$ & 1 & $-\mathrm{CH}_{2} \mathrm{CH}_{3}$ & - & - & -- & + & - & - \\
\hline $4 b-3$ & 1 & $-\mathrm{CH}_{2} \mathrm{CH}_{3}$ & - & - & + & + & - & - \\
\hline $4 c$ & 1 & $-\mathrm{COCH}_{3}$ & + & -- & + & -- & 6.335 & - \\
\hline $4 d$ & 1 & $-\mathrm{Ph}$ & + & -- & + & -- & 3.49 & 7.324 \\
\hline $4 d-1$ & 1 & $-\mathrm{Ph}$ & + & + & - & - & - & - \\
\hline $5 \mathbf{a}$ & 2 & $-\mathrm{CH}_{3}$ & + & + & -- & -- & 4.214 & 7.749 \\
\hline $5 a-1$ & 2 & $-\mathrm{CH}_{3}$ & - & - & + & -- & - & - \\
\hline $5 a-2$ & 2 & $-\mathrm{CH}_{3}$ & - & - & -- & + & - & - \\
\hline $5 a-3$ & 2 & $-\mathrm{CH}_{3}$ & - & - & + & + & - & - \\
\hline $5 b$ & 2 & $-\mathrm{CH}_{2} \mathrm{CH}_{3}$ & + & + & -- & -- & 4.299 & 7.893 \\
\hline $5 b-1$ & 2 & $-\mathrm{CH}_{2} \mathrm{CH}_{3}$ & - & - & + & -- & - & - \\
\hline $5 b-2$ & 2 & $-\mathrm{CH}_{2} \mathrm{CH}_{3}$ & - & - & -- & + & - & - \\
\hline $5 b-3$ & 2 & $-\mathrm{CH}_{2} \mathrm{CH}_{3}$ & - & - & + & + & - & - \\
\hline $5 c$ & 2 & $-\mathrm{COCH}_{3}$ & + & -- & + & -- & 6.592 & - \\
\hline $5 d$ & 2 & $-\mathrm{Ph}$ & + & + & + & -- & 3.681 & 7.581 \\
\hline $5 d-1$ & 2 & $-\mathrm{Ph}$ & + & -- & - & - & - & - \\
\hline
\end{tabular}

+ Protonated, -- not protonated, - not applicable

stretching of ester group. The peaks at 1,398 and $1,163 \mathrm{~cm}^{-1}$ are due to $\mathrm{C}-\mathrm{O}$ and $\mathrm{C}-\mathrm{N}$ stretching vibrations, respectively. The PMR signals of compound (5a) appeared at $\delta 7.62-7.02$ for six naphthalene protons $(\mathrm{Ar}-H)$, a triplet at $\delta 4.07-4.04$ was due to methylene $\left(-\mathrm{CH}_{2}\right)$ protons. A singlet due to methoxy protons $\left(-\mathrm{CH}_{3}\right)$ appeared at $\delta 3.81$ and of methylene protons

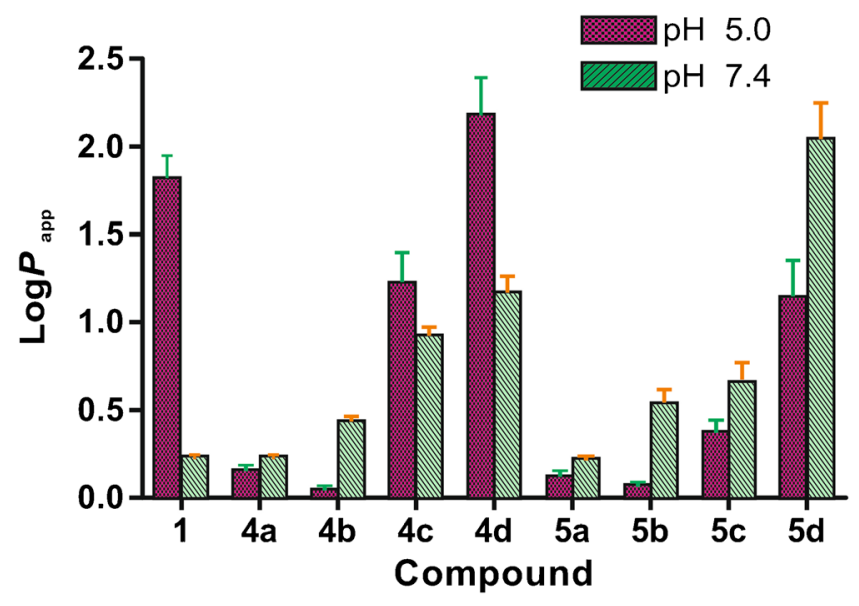

Fig. 1. Comparison of $\log P_{\text {app }}$ values at $\mathrm{pH} 5.0$ and $\mathrm{pH} 7.4, p<0.05$ compared to 6-MNA (1) (ANOVA, Bonferroni's test)

$\left(\mathrm{Ar}-\mathrm{CH}_{2}\right)$ at $\delta$ 3.64. The other methylene protons $\left(\mathrm{N}-\mathrm{CH}_{2}\right)$ showed triplet at $\delta 2.27-2.23$, the piperazine protons appeared as multiplet at $\delta 2.34-2.28$ and $\mathrm{N}$-methyl protons $\left(-\mathrm{CH}_{3}\right)$ appeared at $\delta 2.16$ as a singlet.

Its ${ }^{13} \mathrm{C}$ NMR spectrum shows peaks at 172.76 for carbonyl carbon. Aromatic carbons of naphthalene ring appear in the range of 168.92-105.56, and other aliphatic carbons appeared at $\delta 62.94,55.32-21.31$. The mass spectrum of compound (5a) shows peak at $356.03\left(\mathrm{M}^{+}\right)$which is also the base peak. The compound also showed high chromatographic purity ( $>98 \%$ ) by HPLC.

\section{Aqueous Solubility}

Due to the biphasic nature of skin, an ideal percutaneous prodrug should exhibit adequate lipid as well as aqueous solubility. Aqueous solubility of 6-MNA and its prodrugs were determined at the physiological $\mathrm{pH} 7.4$ and at 5.0, the $\mathrm{pH}$ of the outer surface of the skin ( $\mathrm{pH}$ 4.2-6.5) (3). Generally, an ionized molecule is more water soluble than its unionized form. Because of the acidic character of 6-MNA ( $\left.K_{\mathrm{a}} 4.16\right)$ it is more soluble in aqueous medium at $\mathrm{pH} 7.4$ than at $\mathrm{pH}$ 5.0. On the other hand, piperazinylalkyl ester prodrugs $(\mathbf{4 a}-\mathbf{5 b})$ which possess basic groups $\left(\mathrm{N}^{1}\right.$ and/or $\left.\mathrm{N}^{4}\right)$ are expected to be more ionized at $\mathrm{pH} 5.0$ than at $\mathrm{pH}$ 7.4. The predicted $\mathrm{p} K_{\mathrm{a}}$ of prodrugs $(\mathbf{4 a}-\mathbf{5 d})$ has been shown in Table I. $\mathrm{p} K_{\mathrm{a}}$ values for these structures were calculated using EPIC software at physiological $\mathrm{pH}$ using water as solvent.

Table II. Aqueous Solubility of 6-MNA (1) and Prodrugs (4a-5d) at pH 5.0 and pH 7.4

\begin{tabular}{|c|c|c|c|c|}
\hline \multirow[b]{2}{*}{ Compound } & \multicolumn{2}{|c|}{ Aqueous solubility (mM) } & \multicolumn{2}{|c|}{$\log P_{\text {app }}$} \\
\hline & pH 5.0 & $\mathrm{pH} 7.4$ & pH 5.0 & pH 7.4 \\
\hline 1 & $0.78 \pm 0.18$ & $63.34 \pm 0.24$ & $1.82 \pm 0.12$ & $0.23 \pm 0.02$ \\
\hline $4 \mathbf{a}$ & $23.41 \pm 0.16$ & $21.58 \pm 0.23$ & $0.10 \pm 0.08$ & $0.23 \pm 0.01$ \\
\hline $4 b$ & $26.01 \pm 0.23$ & $12.10 \pm 0.17$ & $0.41 \pm 0.02$ & $0.43 \pm 0.03$ \\
\hline $4 c$ & $1.22 \pm 0.01$ & $1.49 \pm 0.01$ & $1.21 \pm 0.18$ & $0.91 \pm 0.01$ \\
\hline 4d & $0.29 \pm 0.02$ & $0.31 \pm 0.02$ & $2.17 \pm 0.22$ & $1.16 \pm 0.10$ \\
\hline $5 \mathbf{a}$ & $28.41 \pm 0.19$ & $20.09 \pm 0.16$ & $0.12 \pm 0.03$ & $0.22 \pm 0.02$ \\
\hline $5 \mathbf{b}$ & $16.30 \pm 0.14$ & $6.20 \pm 0.03$ & $0.69 \pm 0.02$ & $0.53 \pm 0.08$ \\
\hline $5 c$ & $6.07 \pm 0.02$ & $3.11 \pm 0.01$ & $0.37 \pm 0.07$ & $0.67 \pm 0.01$ \\
\hline $5 d$ & $0.26 \pm 0.01$ & $0.019 \pm 0.002$ & $1.15 \pm 0.21$ & $2.04 \pm 0.21$ \\
\hline
\end{tabular}


<smiles>COc1ccc2cc(CC(=O)OCCN3CC[N+](C)(C)CC3)ccc2c1</smiles>

$4 a$<smiles>COc1ccc2cc(CC(=O)OCCCN3CC[NH+](C)CC3)ccc2c1</smiles>

$5 \mathbf{a}$<smiles>COc1ccc2cc(CC(=O)OC[C@H]3CC[N+]4(CC4)CC[N+](CCO)(C(C)=O)CC3)ccc2c1</smiles>

4c

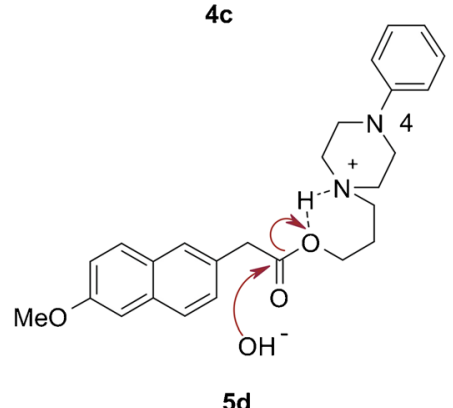

Fig. 2. The chemical structure of prodrugs $(\mathbf{4 a}, \mathbf{5 a})$ protonated at N-4 and the intramolecular hydrogen bonding in prodrug $(\mathbf{4 c}, \mathbf{4 d})$ because of exclusive protonation at $\mathrm{N}-1$

Due to the presence of dibasic groups in prodrugs along with various electron withdrawing or donating substituents at $\mathrm{N}-4$, it is difficult to specify the ionization of these prodrugs at pH 5.0 and 7.4. For understanding, predicted protonated forms of these prodrugs have been determined using Quick prop 32 software and the result obtained has been shown in Table I.

From the data, it could be concluded that at $\mathrm{pH} 5.0$, prodrugs $(\mathbf{4 a}, \mathbf{4 b}, \mathbf{5 a}, \mathbf{5 b})$ get protonated on both the nitrogens $(\mathrm{N}-1,4), \mathbf{4 c}, \mathbf{5 c}$ get protonated only at one nitrogen $(\mathrm{N}-1)$ and prodrugs $(\mathbf{4 d}, \mathbf{5 d})$ get protonated at $\mathrm{N}-1$ or N-4 or both nitrogens. At $\mathrm{pH} 7.4$, prodrugs $(\mathbf{4 a}, \mathbf{4 b}, \mathbf{5 a}, \mathbf{5 b})$ get protonated either at N-1 or N-4 or both nitrogens and prodrugs $(\mathbf{4 c}, \mathbf{5 c})$ get protonated only at one nitrogen $(\mathrm{N}-1)$ due to the presence of a strong electron withdrawing group at N-4. From this data it is concluded that piperazinyl prodrugs $(\mathbf{4 c}, \mathbf{4 d}, \mathbf{5 c}, \mathbf{5 d})$ with electron withdrawing groups at $\mathrm{N}^{4}$ have only one basic ionizable group that makes them less soluble at $\mathrm{pH} 5.0$ with no significant differences observed at $\mathrm{pH}$ 7.4. The aqueous solubility of 6-MNA is higher at $\mathrm{pH} 7.4$ and for piperazinyl prodrugs $(\mathbf{4 a}, \mathbf{4 b}, \mathbf{5 a}, \mathbf{5 b})$ it is higher at $\mathrm{pH}$ 5.0. Overall, substituted piperazinylalkyl prodrugs exhibited higher aqueous solubilities compared to 6-MNA (1) at pH 5.0 except for 4d and 5d. Aqueous solubility of all piperazinylalkyl prodrugs of 6-MNA at $\mathrm{pH} 7.4$ was found to be comparatively lesser than 6-MNA as shown in Table II.

The data showed that aqueous solubility of piperazinyl prodrugs was $\mathrm{pH}$ dependent and lowering the $\mathrm{pH}$ generally increased aqueous solubility of the prodrugs. Substituted piperazinyl promoieties seemed to be suitable for maintaining or increasing the aqueous solubility of 6-MNA in the $\mathrm{pH}$ range of 5.0 to 7.4 .

\section{Determination of Apparent Partition Coefficient $\left(\log \boldsymbol{P}_{\text {app }}\right)$}

Lipid solubility, i.e. lipophilicity plays a crucial role in determining skin permeability of a compound because stratum corneum (SC) the major barrier to drug permeation is essentially lipoidal in nature and generally favors permeation of lipophilic drugs. The apparent partition coefficients of 6-MNA (1) and prodrugs (4a-5d) were determined by partitioning them between phosphate buffer $(0.16 \mathrm{M})$ and saturated 1-octanol at pH 5.0 and pH 7.4 using the shake flask method. The apparent partition coefficients of 6-MNA (1) and prodrugs are listed in Table II.

All of the prodrugs of 6-MNA (1) have retained more or less comparable lipophilicity at $\mathrm{pH} 5.0$ except for derivative (4d, $\log P_{\text {app }}=2.17 \pm 0.05$ ) which is even more lipophilic than 6-MNA (1) $\left(\log P_{\text {app }}=1.82 \pm 0.02\right)$ and derivative (5b) at this $\mathrm{pH}$. At $\mathrm{pH} 7.4$, all the prodrugs showed somewhat increased $\log P_{\text {app }}$ values compared to 6-MNA with a maximum increase in lipophilicity of about ten-fold for prodrug (5d) as shown in Fig. 1.

Although the lipophilicity of most of the prodrugs were lower at $\mathrm{pH} 5.0$ than at $\mathrm{pH} 7.4$, some of them maintained good lipophilicity $\left(\log P_{\text {app }}=0.10-2.17\right)$ at $\mathrm{pH} 5.0$. The lipophilicity of all the prodrugs of 6-MNA (1) varied widely due to changes in promoieties. For an effective dermal penetration, the

Table III. Half-Lives of the Prodrugs in Phosphate Buffer at $\mathrm{pH}$ 5.0, 7.4 and in Human Serum

\begin{tabular}{|c|c|c|c|}
\hline \multirow[b]{3}{*}{ Compound } & \multicolumn{3}{|c|}{$t_{1 / 2}$} \\
\hline & \multicolumn{2}{|c|}{$\begin{array}{l}\text { Phosphate buffer } \\
\qquad\left(t_{1 / 2} \text { in } \mathrm{h}\right)\end{array}$} & \multirow{2}{*}{$\begin{array}{l}\text { Human serum }(80 \%) \\
\left(t_{1 / 2} \text { in } \mathrm{min}\right)\end{array}$} \\
\hline & pH 5.0 & $\mathrm{pH} 7.4$ & \\
\hline $4 \mathbf{a}$ & 79.18 & 17.39 & $46.29 \pm 3.1$ \\
\hline $4 b$ & 250.76 & 21.96 & $37.61 \pm 2.6$ \\
\hline $4 c$ & 27.60 & 27.86 & $11 \pm 1.5$ \\
\hline 4d & 6.9 & 7.5 & $7.8 \pm 1.2$ \\
\hline $5 \mathbf{a}$ & 376.14 & 23.50 & $60.18 \pm 2.1$ \\
\hline $5 \mathbf{b}$ & 601.82 & 45.59 & $29.79 \pm 1.8$ \\
\hline $5 c$ & 158.3 & 30.39 & $10 \pm 1.9$ \\
\hline $5 d$ & $<10.0^{\mathrm{a}}$ & $<10.0^{\mathrm{a}}$ & $8.2 \pm 2.3$ \\
\hline
\end{tabular}

${ }^{a}$ Complete disappearance of derivative within this time interval 


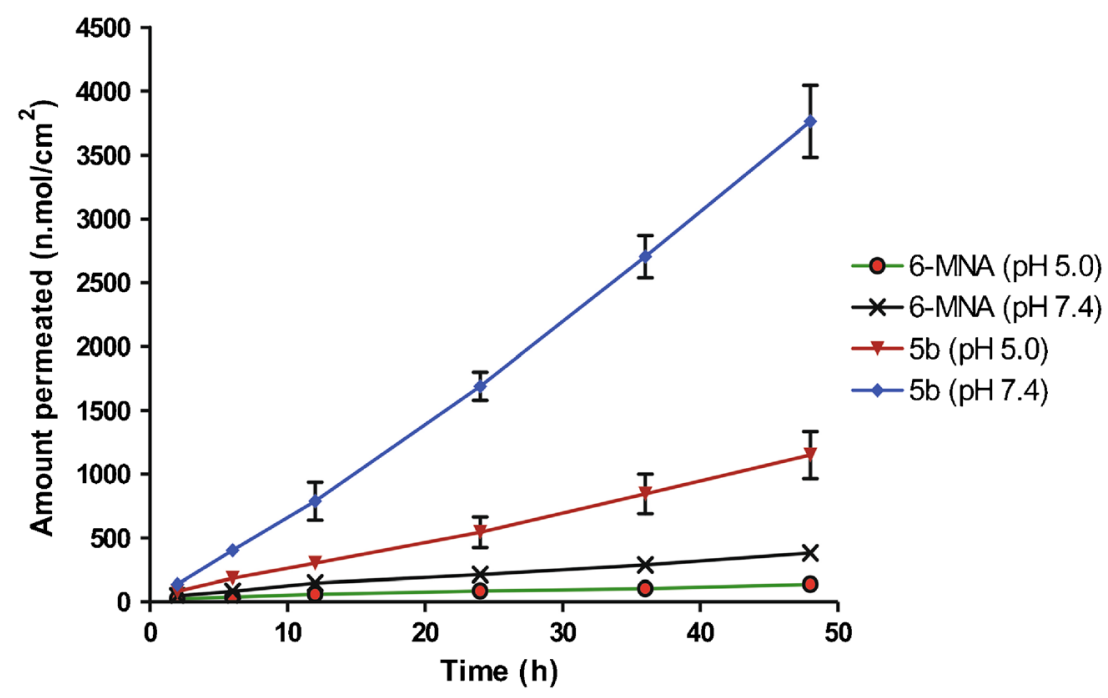

Fig. 3. Permeation profiles (mean $\pm \mathrm{SEM}, n=3-6)$ for (1) and prodrug (5b) at $\mathrm{pH} 5.0$ and 7.4

prodrugs should possess not only high lipophilicity but also adequate aqueous solubilities which got improved in this case by piperazinyl promoieties.

\section{Hydrolyses Kinetics Studies}

Chemical hydrolysis of prodrugs was studied both at physiological $\mathrm{pH} 7.4$ and in acidic $\mathrm{pH} 5.0$ at constant temperature $37 \pm 1^{\circ} \mathrm{C}$ in aqueous buffer solution. The enzymatic hydrolysis kinetics study of the prodrugs was carried out in $80 \%$ human serum. The chemical and enzymatic hydrolyses of all of the 6-MNA prodrugs, followed pseudo-first-order kinetics over several half lives. The aqueous stability of piperazinyl prodrugs was $\mathrm{pH}$ dependent and stabilities were substantially greater at $\mathrm{pH} 5.0$ than at $\mathrm{pH}$ 7.4. The reason for high instability at $\mathrm{pH} 7.4$ is quite obvious as the esters are more prone to hydrolysis in alkaline medium due to higher concentration of hydroxyl nucleophile. Prodrugs $\mathbf{4 c}, \mathbf{4 d}, \mathbf{5 c}, \mathbf{5 d}$ exhibited lowest stability as compared to prodrugs $\mathbf{4 a}, \mathbf{4 b}, \mathbf{5 a}, \mathbf{5 b}$. This can be attributed to the fact that prodrugs $\mathbf{4 c}, \mathbf{4 d}, \mathbf{5 c}$ and $\mathbf{5 d}$ contain electron withdrawing groups at $\mathrm{N}-4$.

Stability of prodrugs $\mathbf{4 c}, \mathbf{4 d}, \mathbf{5 c}$ and $\mathbf{5 d}$ was surprisingly the lowest in acidic $\mathrm{pH}$ because these dibasic prodrugs are not likely to be completely diprotonated at $\mathrm{pH} 5.0$ and remain monopronated at this $\mathrm{pH}$. The prodrugs $\mathbf{4 a}, \mathbf{4 b}, \mathbf{5 a}$,

Table IV. In vitro Steady-State Flux $\left(J_{\mathrm{ss}}\right)$ and Permeability Coefficient $\left(K_{\mathrm{p}}\right)$ of 6 -MNA $(\mathbf{1})$ and the Prodrugs $(\mathbf{4 a}-\mathbf{5 b})$ at $37^{\circ} \mathrm{C}$

\begin{tabular}{cccccr}
\hline & \multicolumn{2}{c}{$K_{\mathrm{p}} \times 10^{6}(\mathrm{~cm} / \mathrm{h})$} & & \multicolumn{2}{c}{$J_{\mathrm{ss}}\left(\mathrm{nmol} / \mathrm{cm}^{2} \mathrm{~h}\right)$} \\
\cline { 2 - 3 } \cline { 6 - 6 } Compound & $\mathrm{pH} 5.0$ & $\mathrm{pH} \mathrm{7.4}$ & & $\mathrm{pH} 5.0$ & $\mathrm{pH} \mathrm{7.4}$ \\
\hline $\mathbf{1}$ & $0.67 \pm 0.03$ & $0.03 \pm 0.01$ & & $0.54 \pm 0.1$ & $1.44 \pm 0.2$ \\
$\mathbf{4 a}$ & $0.10 \pm 0.01$ & $0.32 \pm 0.02$ & & $2.23 \pm 0.14$ & $6.80 \pm 0.3$ \\
$\mathbf{4 b}$ & $0.05 \pm 0.01$ & $0.43 \pm 0.01$ & & $1.37 \pm 0.15$ & $5.17 \pm 0.4$ \\
$\mathbf{5 a}$ & $0.09 \pm 0.01$ & $0.50 \pm 0.02$ & & $2.48 \pm 0.2$ & $9.96 \pm 0.7$ \\
$\mathbf{5 b}$ & $0.26 \pm 0.02$ & $2.59 \pm 0.10$ & & $4.26 \pm 0.4$ & $16.10 \pm 1.5$ \\
\hline
\end{tabular}

$p<0.05$ compared to 6-MNA (ANOVA) 5b would be protonated first at N-4 because it is relatively more accessible and makes them more stable, whereas for prodrugs $4 \mathbf{c}, 4 \mathbf{d d}, \mathbf{5 c}$ and $\mathbf{5 d}$ containing the electron withdrawing groups at $\mathrm{N}-4$ have only $\mathrm{N}-1$ to be protonated. Taking this into consideration, it is possible that these compounds may undergo intramolecular hydrogen bonding between the hydrogen on the protonated nitrogen and the oxygen of the ester group as shown in Fig. 2. Such hydrogen bonding will make the alkoxy moiety a better leaving group facilitating the process of hydrolysis $(11,22)$.

All prodrugs were found to be highly susceptible to enzymatic hydrolysis in human serum in vitro as compared to chemical hydrolysis. They exhibited first-order degradation kinetics and hydrolyzed quantitatively to the corresponding parent drugs. Half-life $\left(t_{1 / 2}\right)$ values of the prodrugs are summarized in Table III.

\section{In Vitro Skin Permeation Study}

In vitro skin permeation studies were performed by using skin obtained from the whole dorsal area of a male Wistar rat in a Franz-type diffusion cell. Skin specimens were rehydrated

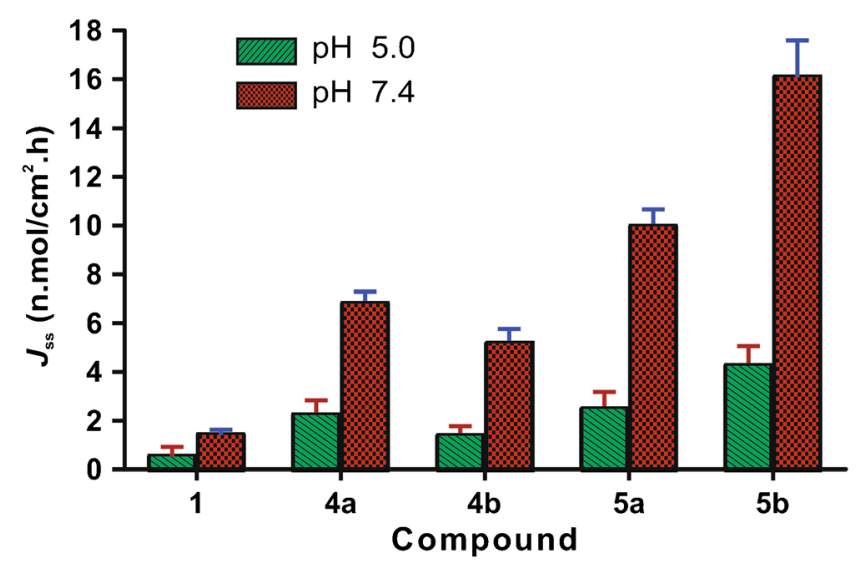

Fig. 4. In vitro steady-state flux $\left(J_{\mathrm{ss}}\right)$ of 6-MNA (1) and the prodrugs $(\mathbf{4 a}-\mathbf{5 b})$ at $37^{\circ} \mathrm{C}$ 
before being mounted in the diffusion cell. The receiver medium (0.05 M phosphate buffer saline solution of $\mathrm{pH} 7.4)$ was stirred and kept at $37 \pm 1^{\circ} \mathrm{C}$ throughout the study. The selected prodrugs $(\mathbf{4 a}-\mathbf{5 b})$ were applied as solutions in phosphate buffer $(0.05 \mathrm{M})$ at both pH 5.0 and 7.4.

The diffusion experiments showed that both 6-MNA (1) and its prodrugs were able to permeate rat skin in vitro. For different prodrugs, the cumulative amounts of permeated 6MNA, or intact prodrug through skin were plotted against time as shown in Fig. 3. A steady-state flux $\left(J_{\mathrm{ss}}\right)$ was calculated by dividing the slope of the linear portion of the graph by surface area of the diffusion cell $(1,7)$. The obtained permeability coefficient $\left(K_{\mathrm{p}}\right)$ for the steady-state delivery and steady-state flux $\left(J_{\mathrm{ss}}\right)$ values of 6-MNA (1) and prodrugs are given in Table IV. All the prodrugs have shown higher flux values than the parent 6-MNA (1).

Amongst all of the prodrugs, prodrug (5b) has shown the highest steady-state flux and $\mathbf{4 b}$ the lowest. Prodrug (5b) with the highest flux had 7.9- and 11.2-fold higher flux than 6-MNA at $\mathrm{pH} 5.0$ and 7.4, respectively. Prodrugs (4a and 5a) have shown intermediate flux values with 4.1- and 4.6-fold higher flux at $\mathrm{pH} 5.0$ and 4.7- and 6.9-fold higher flux at $\mathrm{pH} 7.4$, respectively, than 6-MNA as shown in Fig. 4. The results showed that lipophilic piperazinyl prodrugs with adequate aqueous solubility increased the flux of 6-MNA (1). Permeability coefficient $\left(K_{\mathrm{p}}\right)$ is independent of donor concentration and a useful parameter to evaluate the permeation potential of a compound. The $K_{\mathrm{p}}$ value of all the prodrugs was enhanced several folds compared to 6-MNA at $\mathrm{pH} \mathrm{7.4,}$ however at $\mathrm{pH} 5.0$ all of the prodrugs exhibited low values than 6-MNA because permeability of the compounds from aqueous solution increased as the solubility of the compounds in these solutions decreased. The high $K_{\mathrm{p}}$ value of 5b can be explained by its very low aqueous solubility compared to the other compounds.

The results clearly demonstrated that those prodrugs of 6-MNA (1) which possessed balanced lipid and aqueous solubility, permeated better through the skin than those which had low lipophilicity and poor aqueous solubility. While making a comparison with the previously published work on percutaneous drug delivery, it is concluded that prodrug formation with piperazinylalkyl moieties improves skin permeability significantly $(1,23,24)$.

\section{CONCLUSION}

The present study shows that the permeation of 6-MNA (1) through rat skin can be markedly improved by derivatizing it into piperazinylalkyl prodrugs. The ionizable basic prodrugs combine the desired properties for skin permeation like high aqueous solubility and lipophilicity. Both of these properties can be modulated by changing the substituents on the piperazinyl ring and by varying the alkyl chain length. Increased skin permeability of these prodrugs can be attributed to the combined effect of aqueous solubility and lipophilicity. From the flux and permeability coefficient $\left(K_{\mathrm{p}}\right)$ values it can be concluded that the prodrug $(\mathbf{5 b})$ is the most promising prodrug to improve percutaneous drug delivery of 6-MNA. From this study, it is concluded that an NSAID like 6-MNA having favourable pharmacokinetic and pharmacodynamic properties coupled with its increased permeability through skin by converting it into suitable prodrug like $\mathbf{5 b}$ offer better options for the treatment of rheumatic diseases.

Declaration of Interest The authors report no conflicts of interest. The authors alone are responsible for the content and writing of this article.

\section{REFERENCES}

1. Rautio J, Nevalainen T, Taipale H, Vepsäläinen J, Gynther J, Laine $\mathrm{K}$, et al. Piperazinylalkyl prodrugs of naproxen improve in vitro skin permeation. Eur J Pharm Sci. 2000;11:157-63.

2. Nagarsenker MS, Amin L, Date AA. Potential of cyclodextrin complexation and liposomes in topical delivery of ketorolac: in vitro and in vivo evaluation. AAPS PharmSciTech. 2008;9:1165-70.

3. Suh H, Jun HW, Dzimianski MT, Lu GW. Pharmacokinetic and local tissue disposition studies of naproxen following topical and systemic administration in dogs and rats. Biopharm Drug Disp. 1997;18:623-33.

4. Mikulak SA, Vangsness CT, Nimni ME. Transdermal delivery and accumulation of indomethacin in subcutaneous tissues in rats. J Pharm Pharmacol. 1998;50:153-8.

5. Rautio J, Nevalainen T, Taipale H, Vepsäläinen J, Gynther J, Laine $\mathrm{K}$, et al. Synthesis and in vitro evaluation of novel morpholinyl and methylpiperazinyl acyloxyalkyl prodrugs of 2(6-methoxy-2-naphthyl)propionic acid (Naproxen) for topical drug delivery. J Med Chem. 2000;43:1489-94.

6. Moreira TS, de Sousa VP, Pierre MB. A novel transdermal delivery system for the anti-inflammatory lumiracoxib: influence of oleic acid on in vitro percutaneous absorption and in vivo potential cutaneous irritation. AAPS PharmSciTech. 2010;11:621-9.

7. Duangjit S, Opanasopit P, Rojanarata T, Ngawhirunpat T. Evaluation of meloxicam-loaded cationic transfersomes as transdermal drug delivery carriers. AAPS PharmSciTech. 2013;14:133-40.

8. Barakat NS. Evaluation of glycofurol-based gel as a new vehicle for topical application of naproxen. AAPS PharmSciTech. 2010;11:1138-46.

9. Barry BW. Mode of action of penetration enhancers in human skin. J Control Rel. 1987;6:85-97.

10. Fang L, Numajiri S, Kobayashi D, Morimoto Y. The use of complexation with alkanolamines to facilitate skin permeation of mefenamic acid. Int J Pharm. 2003;262:13-22.

11. Amjad Q, Soraya A. Synthesis of piperazinylalkyl ester prodrugs of ketorolac and their In vitro evaluation for transdermal delivery. Drug Dev Ind Pharm. 2008;34:1054-63.

12. Altman RD. New guidelines for topical NSAIDs in the osteoarthritis treatment paradigm. Curr Med Res Opin. 2010;26:2871-6.

13. Komatsu T, Sakurada T. Comparison of the efficacy and skin permeability of topical NSAID preparations used in Europe. Eur J Pharm Sci. 2012;47:890-5.

14. Davies NM. Clinical pharmacokinetics of nabumetone. The dawn of selective cyclo-oxygenase-2 inhibition? Clin Pharmacokinet. 1997;33:404-16.

15. Friedel HA, Langtry HD, Buckley MM. Nabumetone: a reappraisal of its pharmacology and therapeutic use in rheumatic diseases. Drugs. 1993;45:131-56.

16. Gu L, Dunn J, Dvorak C. Preformulation prodrug researchchemical and enzymatic hydrolysis kinetics of the glycerol, glycolic acid and morpholino ethyl ester derivatives of a developmental analgesic agent (RS-82917). Drug Dev Ind Pharm. 1989;15:209-21.

17. Tammara VK, Narurkar MM, Crider AM, Khan MA. Synthesis and evaluation of morpholinoalkyl ester prodrugs of indomethacin and naproxen. Pharm Res. 1993;10:1191-9.

18. Lobo S, Li H, Farhan N, Yan G. Evaluation of diclofenac prodrugs for enhancing transdermal delivery. Drug Dev Ind Pharm. 2014;40:425-32.

19. Walters KA, editor. Dermatological and transdermal formulations. New York: Marcel Dekker; 2002. p. 119.

20. Arsenijevic L, Arsenijevic V, Horeau A, Jacques J. Synthesis of 2acetyl-6-methoxynaphthalene. Org syn. 1998;6:34-6. 
21. Furniss BS, Hannaford JH, Smith PWG, Tachell AR. Vogel's text book of practical organic chemistry, 5th edition. Singapore: Longman; 1996. p. 987-1054.

22. Akre KP, Gaikar VG. Recovery of 1,4-dimethyl piperazine from aqueous solutions using polymeric adsorbent and ion-exchange resins. Sep Sci Technol. 2006;41:1593-617.
23. Nasr M, Mansour S, Mortada ND, El Shamy AA. Lipospheres as carriers for topical delivery of aceclofenac: preparation, characterization and in vivo evaluation. AAPS PharmSciTech. 2008;9:154-62.

24. Kumbhar D, Wavikar P, Vavia P. Niosomal gel of lornoxicam for topical delivery: in vitro assessment and pharmacodynamic activity. AAPS PharmSciTech. 2013;14:1072-82. 